\title{
POTENSI INFUSA DAUN SIRSAK (ANNONA MURICATA) SEBAGAI DAYA LARV ASIDA LARVA AEDES AEGYPTI
}

\author{
Desto Arisandi*, Maria Theresia Doe Bay, Nurlaili Farida Muhajir \\ Program Studi D3 Analis Kesehatan STIKES Guna Bangsa Yogyakarta \\ 085228015785, destoarisandi@gunabangsa.ac.id
}

\begin{abstract}
Background: Dengue hemorrhagic fever (DHF) which is caused by dengue virus remains a global health problem that belongs to Indonesia also. Transmission works through the bite of female Aedes aegypti. An attempt is developing bioinsecticide with no harm which is involved to vector control such as leaves of the soursop (Annona muricata) that contains active substances such as saponins, tannins, and alkaloids that serves as larvicides.
\end{abstract}

Aims: This research attempted to discover soursop leaves infuse with various concentrations served as larvacide to mortality of larva of $A$. aegypti.

Method: This was a quasi-experimental research with posttest group design which conducted in parasitology laboratory of Poltekkes Kemenkes Yogyakarta. The subjects of research that infuse soursop leaves with a concentration of $15 \%$ and $20 \%$, while the object of research is the number of deaths the third instar larvae of $A$. eagypti after addition of various concentrations of soursop leaf infusion.

Result: Larvicidal activity test soursop leaf infusion using $15 \%$ concentration can kill larvae of $A$. aegypti by $75 \%$, while $20 \%$ concentration can kill larvae of $A$. aegypti by $85 \%$. Statistical analysis using ANOVA test is known that administration of soursop leaves infuse a significant influence against $A$. aegypti larvae mortality $(\mathrm{p}<0.001)$.

Conclusion: Soursop leaves infuse with a concentration of $15 \%$ and $20 \%$ having a larvicidal activity of $A$. aegypti.

Key word: Larva of Aedes aegypti, dengue fever, soursop leaf

\section{PENDAHULUAN}

Penularan penyakit melalui vektor (vector borne diseases) seperti Demam Berdarah Dengue (DBD) masih merupakan masalah kesehatan masyarakat di dunia (Irianto 2009). Indonesia merupakan salah satu daerah endemis DBD dan mengalami epidemi dalam kurung waktu 4-5 tahun sekali. Faktor lingkungan dengan genangan air bersih yang banyak menjadi tempat berkembang biak nyamuk, mobilitas penduduk yang tinggi dan cepatnya transportasi antar daerah menjadi alternatif tingginya penularan penyakit DBD (Soedarto 2012).

Indonesia termasuk negara dengan tingkat kejadian penyakit DBD yang cukup tinggi dengan jumlah dan penyebaran penyakit ke wilayah-wilayah terus meningkat dari tahun ke tahun (Zulkoni 2011). Kejadian DBD pada tahun 2014 hingga pertengahan Desember di 34 provinsi di Indonesia tercatat bahwa penderita DBD sebanyak 71.668 orang 
dan 641 orang diatanranya dilaporkan meninggal dunia (Kementrian Kesehatan Republik Indonesia, 2015).

Perubahan global berpengaruh terhadap risiko penularan penyakit terutama yang ditularkan oleh vektor penyakit. Penularan penyakit DBD sangat sensitif terhadap perubahan lingkungan (Irianto 2009). Penyakit DBD merupakan penyakit yang disebabkan oleh virus dengue melalui perantaraan vektor nyamuk Aedes aegypti dan Aedes albopictus. Kejadian penyakit DBD yang tinggi disebabkan karena iklim tidak stabil dan curah hujan yang cukup tinggi pada musim penghujan menjadi sarana perkembangbiakan nyamuk A. Aegypti (Zulkoni 2011).

Upaya pengendalian penyakit DBD bertumpu pada pengendalian vektor penularan yaitu nyamuk $A$. aegypti, karena hingga saat ini vaksin untuk penyakit DBD belum ditemukan. Pengendalian vektor di Indonesia lebih menitikberatkan kepada program surveilans, pemberantasan sarang nyamuk (PSN) melalui menguras, menutup, dan mengubur (3M plus), menabur larvasida, pemantauan jentik berkala (PJB) yang dapat mencegah atau memberantas nyamuk $A$. aegypti (Badan Perencanaan Pembangunan Nasional, 2006). Pengendalian sebaran nyamuk $A$. aegypti dapat dilakukan dengan insektisida nabati yang berasal dari tumbuh-tumbuhan yang ada disekitar kita (Trisyono 2014).

Indonesia merupakan negara yang memiliki berbagai macam jenis flora, dan mengandung cukup banyak jenis tumbuhtumbuhan yang menjadi sumber bahan insektisida nabati untuk pengendalian vektor penyakit. Insektisida merupakan salah satu teknologi pengendalian untuk membunuh serangga (Trisyono 2014). Daun sirsak mengandung bahan aktif saponin, tanin, dan alkaloid yang mampu membunuh larva A. aegypti. Penelitian yang dilakukan oleh Harfriani (2014) diketahui bahwa infusa daun sirsak 10\% mampu membunuh jentik nyamuk dalam waktu 6 jam pada tempat penampungan air. Berdasarkan hal tersebut maka peneliti tertarik untuk melakukan penelitian mengenai konsentrasi optimum yang dapat membunuh jentik nyamuk $A$. aegypti setelah pemberian infusa daun sirsak dengan berbagai konsentrasi.

\section{METODE PENELITIAN}

Jenis penelitian ini merupakan penelitian quasi experimental dengan desain posttest group design. Subyek pada penelitian ini yaitu infusa daun sirsak dan obyek penelitian yaitu kematian larva A. aegypti instar III. Tempat penelitian dilakukan di laboratorium parasitologi Poltekkes Kemenkes Yogyakarta.

Pembuatan infusa daun sirsak dilkakuan dengan cara metode meserasi menggunakan pelarut etanol $70 \%$. Konsentrasi infusa daun sirsak yang digunakan yaitu $5 \%$ dan $10 \%$. Pengujian efektifitas infusa daun sirsak terhadap kematian larva nyamuk $A$. aegypti dilakukan dengan mengisi gelas plastik sebanyak 3 buah secara berturut-turut dengan air sumur sebagai kontrol, kemudian larutan infusa daun sirsak dengan konsentrasi $15 \%$ dan $20 \%$ sebagai perlakuan. Larva nyamuk $A$. aegypti instar III dimasukkan kepada masing-masing gelas plastik sebanyak 20 ekor. Kematian larva nyamuk $A$. aegypti instar III diamati setelah 24 jam dengan ciri-ciri tidak bergerak jika diberi rangsangan, tidak ada respon gerakan jika disentuh dengan batang pengaduk, bentuk badannya berwarna hitam dan menyudut, serta posisi larva tenggelam.

Data hasil penelitian dianalisis menggunakan program Statistical Product and Service Solution (SPSS) 17.0 for Windows dengan uji statistik one way anova menggunakan uji regresi dengan taraf signifikan $<0,05$ atau derajat kepercayaan $95 \%$.

\section{HASIL DAN PEMBAHASAN}

Uji aktivitas larvasida infusa daun sirsak menggunakan konsentrasi $15 \%$ dan $20 \%$ terhadap larva $A$. aegypti. Masing- 
masing konsentrasi dilakukan pengujian sebanyak 8 kali dan setiap gelas plastik pada saat pengujian dimasukkan larva $A$. aegypti sebanyak 20 ekor. Pengamatan terhadap kematian larva dilihat setelah 24 jam. Hasil penelitian diketahui bahwa konsentrasi infusa daun sirsak sebesar $15 \%$ dapat membunuh larva $A$. aegypti sebesar $75 \%$, sedangkan konsentrasi $20 \%$ sebesar $85 \%$ (Tabel 1 ).

Analisis statistik menggunakan uji Anova diketahui bahwa pemberian infusa daun sirsak dengan konsentrasi $15 \%$ dan $20 \%$ terdapat pengaruh yang signifikan terhadap kematian larva $A$. aegypti ( $\mathrm{p}<$ $0,001)$. Hal ini membuktikan bahwa infusa daun sirsak dapat digunakan sebagai larvasida alami.

Demam berdarah dengue (DBD) merupakan penyakit demam akut yang dapat menyebabkan kematian dan disebabkan oleh 4 serotipe virus dari genus flavivirus, yang merupakan virus ribonucleic acid (RNA) dari famili flaviviridae yaitu virus dengue-1 (DEN-1), dengue-2 (DEN-2), dengue-3 (DEN-3) dan dengue-4 (DEN-4). Keempat virus tersebut telah ditemukan di Indonesia dan virus yang banyak berkembang di masyarakat adalah virus dengue dengan tipe 1 dan tipe 3 (Soedarto 2012).

Tabel 1. Jumlah kematian larva $A$. aegypti terhadap pengujian menggunakan infusa daun sirsak dengan berbagai konsentrasi

\begin{tabular}{cccc}
\hline \multirow{2}{*}{ Pengulangan } & \multirow{2}{*}{ Kontrol } & \multicolumn{2}{c}{ Jumlah kematian larva A. aegypti selama 24 jam } \\
\cline { 2 - 4 } & $0 \%$ & $15 \%$ & Konsentrasi \\
\cline { 2 - 4 } $\mathbf{1}$ & 0 & 11 & $20 \%$ \\
$\mathbf{2}$ & 0 & 18 & 13 \\
$\mathbf{3}$ & 0 & 18 & 14 \\
$\mathbf{4}$ & 0 & 17 & 18 \\
$\mathbf{5}$ & 0 & 16 & 18 \\
$\mathbf{6}$ & 0 & 17 & 19 \\
$\mathbf{7}$ & 0 & 17 & 17 \\
$\mathbf{8}$ & 0 & 16 & 13 \\
Jumlah Kematian & 0 & 120 & 17 \\
Rata-rata & 0 & 15 & 85 \\
\hline Persentase (\%) & 0 & 75 & \\
\hline
\end{tabular}

Virus dengue ditularkan dari orang ke orang melalui gigitan nyamuk betina Ae. aegypti dan Ae. albopictus. Daerah distribusi geografis nyamuk Ae. aegypti dan Ae. albopictus terbatas. Aedes albopictus merupakan vektor epidemi yang kurang efisien dibandingkan dengan Ae. aegypti (Zulkoni 2011). Penularan virus dengue dipengaruhi oleh dua faktor, yaitu faktor biotik dan abiotik. Faktor biotik adalah virus penyebab vektor penularan dan hospes, sedangkan faktor abiotik adalah suhu udara, kelembaban dan curah hujan (Soedarto 2012).

Penularan penyakit DBD terjadi melalui gigitan nyamuk $A$. aegypti atau $A$. albopictus betina dewasa yang di dalam tubuhnya terdapat virus dari penderita DBD sebelummnya. Nyamuk $A$. aegypti menggigit manusia pada waktu pagi hari (setelah matahari terbit) dan siang hari (sampai sebelum matahari terbenam). Orang yang berisisko terkena penyakit DBD adalah anak-anak yang berusia di bawah 15 tahun dan yang tinggal di lingkungan lembab, serta pinggiran kumuh (Zulkoni 2011).

Penderita pertama kali menderita DBD biasanya tidak menunjukkan adanya gejala (asimtomatik) atau timbul demam yang tidak khas. Gejala demam dengue (DD) yang klasik yaitu demam tinggi yang terjadi mendadak, sakit kepala, nyeri di belakang bola mata (retro-orbital), rasa sakit pada otot dan 
tulang, badan lemah, sakit tenggorokan, ruam pada kulit dan muntah. Rasa nyeri otot dan tulang pada penderita DBD sering disebut dengan demam patah tulang (breakbone fever). Penderita yang pernah terinfeksi satu serotipe virus dengue, ketika mengalami infeksi kedua oleh serotipe yang lain, makan dapat menyebabkan pendarahan dan kerusakan endotel atau vaskulopati, yang biasa disebut dengan DBD atau dengue vaskulopati (Soedarto 2012).

Kriteria seseorang yang terinfeksi virus DBD biasanya mengalami trombositopenia (trombosit $<100.000 / \mathrm{ml}$ ) dan hemokonsentrasi (kenaikan hematokrit $>20 \%$ ). Gejala klinis penyakit DBD tidak begitu spesifik, sehingga diperlukan pemeriksaan laboratorium untuk memastikan diagnosis infeksi DBD. Diagnosis serologi dapat dilakukan dengan pemeriksaan laboratorium yaitu peningkatan titer antibodi $\lg G$ dan $\lg M$ (Soedarto 2012).

Nyamuk betina $A$. aegypti bertelur sebanyak 50-120 butir di tempat yang mengandung air, misalnya pada vas bunga, bak air di kamar mandi, bejana penyimpan air, gelas plastik, dan wadah yang berisi air hujan di luar rumah dapat menjadi tempat berkembang biak nyamuk. Telur $A$. aegypti diletakkan di atas permukaan air atau sedikit di permukaan garis batas (Soedarto 2012).

Telur $A$. aegypti berbentuk lonjong, panjang $\pm 0,6 \mathrm{~mm}$ dan berat $0,0133 \mathrm{mg}$. Telur berwarna putih pada saat diletakkan, kemudian telur menjadi abuabu setelah 15 menit dan telur menjadi hitam setelah 40 menit. Dinding telur terdapat garis-garis seperti kawat kasa atau sarang tawon (Sungkar 2005). Telur nyamuk $A$. aegypti di dalam air dengan dengan suhu $20-40^{\circ} \mathrm{C}$ akan menetas menjadi larva dalam waktu 1-2 hari (Hendra, 2007). Telur nyamuk dalam keadaan kering dapat bertahan hidup sampai satu tahun, tetapi jika suhu kurang dari $10^{\circ} \mathrm{C}$ maka akan segera mati (Soedarto 2012).

Larva $A$. aegypti melalui 4 stadium larva dari instar I, II, III dan IV. Larva instar I, tubuhnya sangat kecil, warna transparan, panjang 1-2 mm, duri-duri (spinae) pada dada (thorax) belum begitu jelas, dan corong pernapasan (siphon) belum menghitam. Larva instar II, ukuran 2,5-3,9 mm, duri dada belum jelas, corong pernapasan sudah berwarna hitam. Larva instar III berukuran 4-5 mm, duri dada mulai jelas dan corong pernapasan berwarna cokelat kehitaman. Larva instar IV struktur anatomi sudah lengkap dan tubuh dapat dibagi menjadi bagian kepala (caput), dada (thorax), dan perut (abdomen). Larva instar IV mempunyai tanda khas yaitu pelana yang terbuka pada segmen anal, sepasang bulu siphon dan gigi sisir berduri lateral pada segmen abdomen ke-7. Kecepatan pertumbuhan dan perkembangan larva dipengaruhi beberapa faktor, yaitu temperatur, tempat, keadaan air dan kandungan zat makanan yang ada di dalam tempat perindukan. Larva berkembang menjadi pupa dalam waktu 4-9 hari paa kondisi optimum, kemudian pupa menjadi nyamuk dewasa dalam waktu 2-3 hari. Pertumbuhan dan perkembangan telur, larva, pupa, sampai dewasa memerlukan waktu kurang lebih 7-14 hari (Hendra, 2007).

Habitat alami larva nyamuk $A$. aegypti dapat dijumpai di daerah urban, misalnya lubang pohon, pelepah daun pisang, tempurung kelapa. Daerah yang penyediaan air tidak teratatur, menyimpan air dalam tandon-tandon atau wadah persediaan air yang lain dapat meningkatkan jumlah habitat nyamuk dan menjadi tempat berkembang biak (Soedarto 2012).

Telur, larva, dan pupa nyamuk $A$. aegypti tumbuh dan berkembang di dalam air. Genangan yang disukai sebagai tempat perindukan nyamuk $A e$. aegypti berupa genangan air yang tertampung di suatu tempat penampungan bukan genangan air tanah. Tempat perindukan yang paling potensial adalah tempat Penampung Air (TPA) yang digunakan sehari-hari seperti drum, tempayan, bak mandi, bak wc, ember dan sejenisnya. Tempat perindukan tambahan adalah disebut non-TPA, seperti tempat minum hewan, barang bekas, dan vas bunga, sedangkan TPA alami seperti lubang 
pohon, lubang batu, pelepah daun, tempurung kelapa, kulit kerang, pangkal pohon pisang dan potongan bambu. Nyamuk $A$. aegypti lebih tertarik untuk meletakkan telur pada TPA yang berwarna gelap, paling menyukai warna hitam, terbuka lebar, dan terutama terletak di tempat yang terlindung dari sinar matahari (Hendra, 2007).

\section{KESIMPULAN}

Infusa daun sirsak dengan konsentrasi $15 \%$ dan $20 \%$ mempunyai aktivitas sebagai larvasida nyamuk $A$. aegypti. Konsentrasi infusa daun sirsak yang semakin tinggi berpengaruh terhadap peningkatan jumlah mortalitas larva nyamuk $A$. aegypti.

\section{DAFTAR PUSTAKA}

Irianto, K., 2009. Malaria Klinik: Morfologi Darah Tepi Pada Penderita Malaria, Jakarta: Penerbit Buku Kedokteran, EGC.

Mustarichie, R., Musfiroh, I. \& Levita, I., 2011. Metode Penelitian Tanaman Obat, Padjajaran: Widya.

Novizan, 2002. Membuat dan Memanfaatkan Pestisida Ramah Lingkungan, Jakarta: Media Pustaka.

Soedarto, 2012. Demam Berdarah Dengue, Jakarta: Sagung Seto.

Sungkar, S., 2005. Binomik Aedes aegypti, Vektor Demam Berdarah Dengue. Majalah Kedokteran Indonesia, 55(4).

Trisyono, A., 2014. Insektisida Pengganggu Pertumbuhan dan Perkembangan Serangga, Yogyakarta: Gajah Mada University Press.

Zulkoni, 2011. Parasitologi Untuk Keperawatan, Kesehatan Masyarakat dan Teknik Lingkungan, Yogyakarta: Nuha Medika. 